\section{THU0161 SYNDECANS ARE CORRELATED WITH HIGH TITRES OF ANTIBODIES AGAINST CITRULLINATED PROTEINS ANTIGENS (ACPAS) IN SERA FROM ACTIVE RHEUMATOID ARTHRITIS}

N.A. Rodriguez-Jimenez ${ }^{1}$, E.G. Cardona-Muñoz ${ }^{2}$, J.I. Gamez-Nava ${ }^{1}$,

E.E. Perez-Guerrero ${ }^{3}$, M. Ponce-Guarneros ${ }^{4}$, E.Y. Vera-Navarrete ${ }^{3}$,

A. Nava-Zavala ${ }^{1}$, T.A. Garcia-Cobian ${ }^{2}$, M. Salazar-Paramo ${ }^{1}$,

L. Gonzalez-Lopez ${ }^{5}$. 1 UMAE, Hospital de Especialidades Centro Medico de Occidente, Instituto Mexicano del Seguro Social; ${ }^{2}$ Universidad de Guadalajara, Guadalajara, Mexico; ${ }^{3}$ Doctorado en Farmacologia, Universidad de Guadalajara, Guadalajara; ${ }^{4}$ Unidad de Medicina Familiar No. 97, IMSS, Magdalena, Jalisco;

${ }^{5}$ Hospital General Regional No. 110, IMSS, Guadalajara, Mexico

Background: Syndecans includes a group of proteins from the cell-surface heparan-sulfate proteoglycan family, with a relevant role in chronic inflammation of synovial tissue in patients with rheumatoid arthritis (RA) participating in the cell-matrix and cell-cell interactions. Syndecans are differentially expressed in the synovial tissue: syndecan-1 (SDC-1) is expressed mainly in mononuclear cells, syndecan-3 (SDC-3) is mainly expressed by synovial endothelial cells and syndecan-4 (SDC-4) is expressed by B lymphocytes regulating B cell development and survival. Currently, there is strong evidence that antibodies directed to citrullinated protein antigens (ACPAs) are associated with a more severe disease in RA. Nevertheless, to date, there is a lack of information about the relation between serum syndecan levels and serum concentrations of rheumatoid factor (RF) and ACPAs.

Objectives: To evaluate the association between serum SDC-1, SDC-3 and SDC-4 levels with serum concentrations of RF and ACPAs.

Methods: Eighty-one, patients with RA were included. We assessed clinical characteristics including disease activity by DAS-28, functioning by HAQ-Di. Serum concentrations of RF were measured by nephelometry, two ACPAs were measured: anti-CCP2 and anti-mutated citrullinated vimentin (anti-MCV) antibodies using ELISA. Serum levels of SDC-1, SDC-3 $(\mathrm{ng} / \mathrm{mL})$ and SDC-4 $(\mathrm{pg} / \mathrm{mL})$ were measured by ELISA. We compared the serum levels of these syndecans in the ACPA+ group (group 1) versus ACPA- group (group 2) with Student t-test. A correlation analysis (Pearson tests) was performed to identify the strength of association between concentrations of syndecans with concentrations of ACPAs and other variables.

Results: Patients with RA had a mean age of $50 \pm 11$ yrs, $75 \%$ were RF+ and $64 \%$ were ACPA+. In patients with ACPAs+ were observed higher serum concentrations of SDC-3 $(p=0.003)$ and SDC-4 $(p<0.001)$. SDC- 1 correlated significantly with anti-MCV $(r=0.53, p<0.001)$. Serum concentrations of SDC-3 correlated significantly with anti-CCP titres $(r=0.53, p=0.003)$ and anti-MCV $(r=0.46, p=0.02)$; whereas SDC-4 levels correlated significantly with anti-CCP titres $(r=0.61, p<0.001)$ and $R F(r=0.53, p=0.003)$. Additionally, serum SDC-1 levels correlated with decrement in response to treatment with synthetic DMARDs $(r=-0.25, p=0.026)$. SDC-1 did not correlate with serum SDC-3 $(p=0.8)$ and SDC-4 $(p=0.8)$; whereas serum SDC-3 and SDC-4 had a strong correlation $(r=0.8$, $p<0.001$ ).

Conclusions: Serum SDC-3 and SDC-4 are increased in ACPA-positive RA patients. These data suggest that syndecans might be useful as serum biomarkers for discriminate a group of patients with RA and more severe disease. References:

[1] Patterson AM, et al. Ann Rheum Dis. 2008 May;67(5):592-601.

[2] Endo T, et al. Arthritis Rheumatol. 2015 Sep;67(9):2512-22.

Acknowledgements: This project was supported by a grant from the Fondo de Investigacion en Salud del Instituto Mexicano del Seguro Social: FIS/IMSS/PROT/G15/1448.

Disclosure of Interest: N. Rodriguez-Jimenez: None declared, E. CardonaMuñoz: None declared, J. Gamez-Nava: None declared, E. Perez-Guerrero: None declared, M. Ponce-Guarneros: None declared, E. Vera-Navarrete: None declared, A. Nava-Zavala: None declared, T. Garcia-Cobian: None declared, M. Salazar-Paramo: None declared, L. Gonzalez-Lopez Grant/research support from: Dr. L Gonzalez-Lopez is a recipient of a Fundacion IMSS Scholarship, Mexico.

DOI: 10.1136/annrheumdis-2017-eular.4965

\section{THU0162 RELATIONSHIP BETWEEN LEVELS OF HUMAN PEPTIDYL ARGININE DEIMINASE-4 WITH CHRONIC PERIODONTITIS SEVERE IN RHEUMATOID ARTHRITIS}

O. Vega ${ }^{1}$, T. Rubin de Celis ${ }^{1}$, D. Tamayo ${ }^{2}$, R. Flores ${ }^{2}$, A. Madariaga ${ }^{3}$, Y. Laura ${ }^{4}$, R. Gamboa ${ }^{5} .{ }^{1}$ Rheumatology, Reumacenter; ${ }^{2}$ Medicine; ${ }^{3}$ Dentistry, Hospital III, EsSalud; ${ }^{4}$ Immunology, Reumacenter, Juliaca; ${ }^{5}$ National Hospital Guillermo Almenara, Essalud, Lima, Peru

Background: Both Peptydil arginine deiminase of $P$. gingivalis (pPAD), and the human enzyme (hPAD), could citrullinarize peptides from the bacteria and human host in Rheumatoid Arthritis patients (RA). Chronic periodontitis (CP) could be associated with a constant generation of citrullinated proteins, and it lead to a proportional hPAD enzymatic production.

Objectives: The aim was to demonstrate the association between serum levels of hPAD4 and severe Periodontitis in patients with rheumatoid arthritis.

Methods: Patients with RA $(n=127)$ matched with healthy controls $(n=120)$ were studied in a cross-sectional study. Levels of human recombinant antigens for hPAD4; cyclic citrullinated peptide antibody (CCP3, $\lg G)$, Rheumatoid factor (IgM) and $\mathrm{C}$-reactive protein (CRP); determined by ELISA test.

The CP was classified according to the recommendations of the International Workshop for Classification of Periodontal Diseases and Conditions. Bivariate analysis to demonstrate the associations, and non-parametric analyzes were used according to the case.

Results: There were no significant demographic diffrences between the two groups. The median hPAD4 level was $1.21(95 \% \mathrm{Cl} 1.4-1.7)$ in RA and $0.75(95 \%$ $\mathrm{Cl} 0.94-1.26) \mathrm{ng} / \mathrm{ml}$ in controls, $(\mathrm{p}<0.004)$. The median hPAD4 level in patients with RA and CP was $1.32(95 \% \mathrm{Cl} 1.39-1.9)$ Vs control with $\mathrm{CP} 0.7(95 \% \mathrm{Cl}$ $0.94-1.5) \mathrm{ng} / \mathrm{ml}, \mathrm{p}<0.04$.

The frequency of CP was higher in patients with RA than in controls (66.9 vs $43 \%$, $\mathrm{p}<0.000$; OR: 2.65 (95\% Cl: 1.58-4.44); these values showed a low correlation $(0.24)$. The median level of hPAD4 was associated with CP extension, $p<0.000$ and severity, $\mathrm{p}<0.000$.

A significant correlation was found between levels of hPAD4 with the DAS28 ESR score $(p<0.002)$. The high score of HAQ-DI $(>2.0)$ correlated with hPAD4 levels $(P<0.001)$. The group of people with higher HAQ-DI score and at the same time with greater severity of CP $(n=12)$ showed increased levels PAD4 $(p<0.025)$.

Conclusions: hPAD4 levels correlate with the severity of CP independent of the RA presence and in RA subjects with high score of disability and activity disease. The hPAD4 could be proposed as a serological marker of clinical severity in chronic diseases such as $\mathrm{CP}$ and RA.

References:

[1] Rose, H.M., C. Ragan, and et al., Differential agglutination of normal and sensitized sheep erythrocytes by sera of patients with rheumatoid arthritis. Proc Soc Exp Biol Med, 1948. 68(1): p. 1-6.

[2] Girbal-Neuhauser, E., et al., The epitopes targeted by the rheumatoid arthritisassociated antifilaggrin autoantibodies are posttranslationally generated on various sites of (pro)filaggrin by deimination of arginine residues. J Immunol, 1999. 162(1): p. 585-94

[3] Lundberg, K., et al., Antibodies to citrullinated alpha-enolase peptide 1 are specific for rheumatoid arthritis and cross-react with bacterial enolase. Arthritis Rheum, 2008. 58(10): p. 3009-19.

[4] Mikuls, T.R., et al., Periodontitis and Porphyromonas gingivalis in patients with rheumatoid arthritis. Arthritis Rheumatol, 2014. 66(5): p. 1090-100.

Disclosure of Interest: None declared

DOI: 10.1136/annrheumdis-2017-eular.3358

\section{THU0163 THE ASSOCIATION BETWEEN INFLAMMATORY JOINT DISORDERS AND CORONARY HEART DISEASE: NATIONWIDE REGISTER STUDY IN 50444 PATIENTS}

P. Muilu $^{1}$, V. Rantalaiho ${ }^{2,3}$, H. Kautiainen ${ }^{4,5}$, L. Virta ${ }^{6}$, K. Puolakka $^{7}$ ${ }^{1}$ Department of Medicine, Tampere University Hospital; ${ }^{2}$ Centre for Rheumatic Diseases, Tampere University Hospital; ${ }^{3}$ Faculty of Medicine and life sciences, University of Tampere, Tampere; ${ }^{4}$ Department of General Practice and Primary Health Care, University of Helsinki and Helsinki University Hospital, Helsinki, ${ }^{5}$ Unit of Primary Health Care, Turku University Hospital; ${ }^{6}$ Social Insurance Institution of Finland, Turku; ${ }^{7}$ Department of Medicine, South-Karelia Central Hospital, Lappeenranta, Finland

Background: Inflammatory joint disorders (IJD) are associated with cardiovascular (CV) problems, including coronary heart disease (CHD). This association is best known for rheumatoid arthritis (RA); but also for ankylosing spondylitis and

Table 1. A) The prevalence of coronary heart disease (CHD) at the index date among patients with inflammatory joint diseases (IJD's) compared to their controls. B) The incidence of CHD among IJD patients compared to the controls during follow up.

\begin{tabular}{|c|c|c|c|c|c|c|c|}
\hline \multirow[b]{3}{*}{ Men } & \multirow[b]{3}{*}{$\mathbf{N}$} & \multicolumn{3}{|c|}{ A) Index datea } & \multicolumn{3}{|c|}{ B) Follow up b } \\
\hline & & & $\begin{array}{l}\text { CHD } \\
\%\end{array}$ & $\begin{array}{c}\text { OR } \\
(95 \% \mathrm{CI})\end{array}$ & $\begin{array}{c}\text { Incid } \\
\text { per }\end{array}$ & $\begin{array}{l}\text { ce of CHD } \\
0 \text { patient } \\
\text { ears }\end{array}$ & IRR \\
\hline & & Case & Control $^{\mathrm{e}}$ & & Case & Control & \\
\hline $\mathrm{RA}+$ & 6004 & 11.5 & 9.9 & $\begin{array}{c}1.20 \\
(1.09 \text { to } 1.33)\end{array}$ & 8.3 & 5.8 & $\begin{array}{c}1.46 \\
\text { (1.27 to } 1.67)\end{array}$ \\
\hline RA- & 3071 & 10.3 & 9.2 & $\begin{array}{c}1.14 \\
(0.98 \text { to } 1.31)\end{array}$ & 6.1 & 5.4 & $\begin{array}{c}1.12 \\
(0.92 \text { to } 1.37)\end{array}$ \\
\hline UA & 2503 & 5.9 & 5.8 & $\begin{array}{c}1.03 \\
(0.84 \text { to } 1.26)\end{array}$ & 5.8 & 3.8 & $\begin{array}{c}1.51 \\
\text { (1.19 to } 1.93)\end{array}$ \\
\hline SpA & 4349 & 1.6 & 1.3 & $\begin{array}{c}1.21 \\
(0.90 \text { to } 1.64)\end{array}$ & 2.3 & 1.6 & $\begin{array}{c}1.44 \\
(1.09 \text { to } 1.89)\end{array}$ \\
\hline $\begin{array}{r}\text { PsA } \\
\text { Wome }\end{array}$ & 3424 & 3.9 & 3.9 & $\begin{array}{c}1.04 \\
\text { (0.84 to } 1.28)\end{array}$ & 4.5 & 3.3 & $\begin{array}{c}1.36 \\
(1.09 \text { to } 1.70)\end{array}$ \\
\hline RA+ & 12159 & 5.1 & 4.8 & $\begin{array}{c}1.05 \\
(0.95 \text { to } 1.16)\end{array}$ & 2.6 & 2.3 & $\begin{array}{c}1.14 \\
\text { (0.98 to } 1.32)\end{array}$ \\
\hline RA- & 6713 & 5.7 & 4.7 & $\begin{array}{c}1.26 \\
\text { (1.11 to } 1.44)\end{array}$ & 2.6 & 2.0 & $\begin{array}{c}1.32 \\
\text { (1.08 to } 1.61)\end{array}$ \\
\hline UA & 4896 & 3.0 & 2.7 & $\begin{array}{c}1.11 \\
(0.90 \text { to } 1.36)\end{array}$ & 2.5 & 1.5 & $\begin{array}{c}1.67 \\
\text { (1.28 to } 2.18)\end{array}$ \\
\hline SpA & 4047 & 0.8 & 0.6 & $\begin{array}{c}1.37 \\
(0.89 \text { to } 2.11)\end{array}$ & 0.8 & 0.6 & $\begin{array}{c}1.42 \\
\text { (0.87 to } 2.31)\end{array}$ \\
\hline PsA & 3278 & 2.0 & 1.6 & $\begin{array}{c}1.23 \\
(0.91 \text { to } 1.67)\end{array}$ & 2.2 & 1.5 & $\begin{array}{c}1.53 \\
(1.10 \text { to } 2.13)\end{array}$ \\
\hline
\end{tabular}

"The date when the special reimbursement for IJD came effective

${ }^{b}$ The time period after the index date until Dec 31st 2014

- Three control subjects were matched for each patient with IJD 